\title{
Persepsi warga mengenai perilaku hidup bersih dan sehat di Dusun Kebonan, Semarang
}

\author{
The society perception about clean and healthy behavior \\ in Kebonan Village, Semarang
}

\author{
Aprillia Vanessha Mailoa, Maria Dyah Kurniasari, Tesabela Sanfia Messakh \\ Fakultas Kedokteran dan Ilmu Kesehatan, Universitas Kristen Satya Wacana \\ Jalan Kartini NO 11 A Salatiga 50711, Telepon: 082226886169, Faksimile: 0298-321433 \\ E-mail: maria.dyah@staff.uksw.edu
}

\begin{abstract}
Kebonan Village, Semarang Regency, Central Java is the region with the highest number of diarrhea cases. Based on the profile of Puskesmas Regency/City Semarang in 2014, there were 84 findings of diarrhea cases. The initial observation revealed that living environment in Kebonan village was not hygiene. Most of the times, the ditch loaded by garbage, the food often surrounded by flies, people often do not wash their hands after completing their daily activities, and there are houses that still have no latrines. These behaviors were not in accordance with the Clean and Healthy Behavior, thus estimated as the main cause of high cases of diarrhea in Kebonan. This situation was in opposition with Government socialization to local residents about Clean and Healthy Behavior (Perilaku Hidup Bersih dan Sehat/PHBS). Therefore, the problem identified in this research is the failure of government programs through the Department of Health in disseminating the importance of PHBs which resulting in the high number of diarrhea. The aim of this study is to describe the perception of citizens about the PHBS in Kebonan Village, Semarang. This study used the qualitative method with the descriptive design. Researcher employs primary and secondary data. Primary data collected through in-depth interviews with residents of Kebonan, while secondary data was gathered through observations. Data validity was further tested through member-checking method. The research concludes that the perception of Kebonan residents on PHBs are divided into three aspects: realizing the physical and environmental cleanliness, who is responsible for realizing PHBs, and constraints in realizing PHBS. Citizen roles to keep the environment clean, manage domestic waste, use a proper toilet, washing hand and bathing, and keeping female organ hygiene are essential in creating a good and clean living environment.
\end{abstract}

Keywords: perception, clean and healthy behavior, Kebonan village

\begin{abstract}
Abstrak
Desa Tolokan, Kecamatan Getasan, Kabupaten Semarang, Jawa Tengah memiliki angka kasus diare tertinggi. Berdasarkan profil Puskesmas Kabupaten/Kota Semarang tahun 2014, terdapat 84 temuan kasus diare. Hasil observasi yang didapatkan adalah lingkungan rumah yang kurang bersih baik di dalam maupun di luar, selokan yang penuh dengan banyak sampah, makanan yang sering dikerumuni lalat, warga yang sering tidak mencuci tangan sehabis beraktivitas, kandang hewan yang dibangun dalam satu atap dengan keluarga, serta masih ada warga yang belum memiliki jamban. Data tersebut menunjukkan adanya perilaku-perilaku warga yang tidak sesuai dengan Perilaku Hidup Bersih dan Sehat (PHBS), sehingga diperkirakan penyebab tingginya kasus diare akibat perilaku tersebut meskipun sosialisasi mengenai Perilaku Hidup Bersih dan Sehat telah dijalankan oleh pemerintah. Peneliti mengidentifikasi masalah yang terjadi yaitu adanya ketidakberhasilan program pemerintah melalui Dinas Kesehatan dalam mensosialisasikan pentingnya PHBS dan mengakibatkan tingginya penderita diare. Penelitian ini ingin menggambarkan persepsi warga mengenai PHBS, sehingga hasil penelitian ini dapat menjadi bahan pertimbangan pemerintah, dalam hal ini Dinas Kesehatan setempat dalam merancang program bagi masyarakat. Metode yang digunakan dalam penelitian ini adalah kualitatif deskriptif. Jenis data yang digunakan adalah data primer dan data sekunder. Teknik pengumpulan data primer melalui wawancara mendalam dengan warga Dusun Kebonan, sedangkan data sekunder dengan melakukan observasi. Uji keabsahan data menggunakan member-checking. Dari penelitian ini dapat disimpulkan bahwa persepsi warga Dusun Kebonan mengenai PHBS terbagi menjadi tiga tema, yaitu mewujudkan kebersihan fisik dan lingkungan, PHBS tanggung jawab siapa, dan kendala dalam PHBS. Peran individu dan warga sangat dibutuhkan dalam menciptakan lingkungan yang bersih dan sehat dengan cara menjaga kebersihan lingkungan fisik, mengolah sampah RT, menggunakan jamban, mencuci tangan, mandi serta menjaga kebersihan organ kewanitaan, karena lingkungan yang bersih bergantung pada perilaku.
\end{abstract}

Kata Kunci: persepsi, perilaku hidup bersih dan sehat, Dusun Kebonan 


\section{Pendahuluan}

Penelitian ini dilakukan awal pada bulan 13 April-5 Mei 2016 di salah satu dusun di Desa Tolokan yaitu Dusun Kebonan. Observasi dilakukan kurang lebih selama 1 bulan. Hasil observasi yang didapatkan adalah lingkungan rumah terlihat kurang bersih baik di dalam maupun di luar akibat sampah yang berserakan, selokan yang memiliki banyak sampah, makanan yang sering dikerumuni lalat, warga yang sering tidak mencuci tangan sehabis beraktivitas di ladang maupun di kebun, warga juga membangun kandang hewan peliharaan dalam satu atap dengan pemilik rumah serta masih ada warga yang belum memiliki jamban. Hal inilah yang menyebabkan peneliti memperkirakan penyebab tingginya kasus diare ini akibat perilaku warga yang kurang menjaga kebersihan dan juga kesehatan lingkungan tempat tinggal maupun lingkungan sekitar. Perilaku-perilaku yang demikian belum sesuai dengan indikator Perilaku Hidup Bersih dan Sehat (PHBS) di antaranya mencuci tangan dengan air bersih dan sabun, memakai jamban sehat, melakukan aktivitas fisik setiap hari, mengonsumsi buah dan sayur setiap hari, tidak merokok dalam rumah, penggunaan air bersih, dan pemberantasan jentik nyamuk (Riskesdas 2013).

Merujuk pada indikator PHBS di atas maka dapat dilihat bahwa masih ada beberapa hal yang belum terpenuhi yaitu: (1) tidak memiliki jamban, (2) jarang mencuci tangan setelah beraktivitas (berladang dan berkebun), (3) masih berperilaku merokok, dan (4) jarang untuk membersihkan tempat penampungan air. Padahal warga setempat sudah sering kali mengikuti sosialisasi terkait PHBS dari Dinas Kesehatan yang bekerja sama dengan seluruh perangkat Desa. Pernyataan ini dibenarkan oleh kepala Dusun Kebonan saat diwawancarai oleh peneliti pada tanggal 8 Juli 2015. Dari masalah tersebut, teridentifikasi masalah bahwa adanya kegagalan program pemerintah dalam upaya perbaikan status kesehatan masyarakat dalam bentuk sosialisasi PHBS. Menurutnya, persoalan kesehatan warga Dusun Kebonan umumnya disebabkan oleh kebiasaan dalam budaya masyarakat Jawa yang menganggap jika penyakit belum mengakibatkan seseorang berhenti beraktivitas, maka mereka akan terus bekerja. Artinya, jika penyakit tersebut tidak dirasakan berbahaya atau sampai menghambat aktivitas, maka itu bukan masalah besar yang harus ditakutkan; meskipun mereka aktif mengikuti sosialisasi tentang PHBS dan ancaman penyakit akibat tidak diterapkannya PHBS. Pernyataan tersebut sesuai dengan penelitian terdahulu oleh Gomo et al. (2013) yang mengungkapkan bahwa PHBS seseorang atau masyarakat, ditentukan oleh sudut pandang (persepsi), pengetahuan, sikap, kepercayaan, tradisi dari masyarakat yang bersangkutan. Tanpa disadari persepsi dan perilakuperilaku hidup bersih dan sehat yang tidak sesuai akan menimbulkan kelompok-kelompok beresiko tinggi. Bagi mereka yang memiliki persepsi mengenai PHBS yang tidak sesuai dengan konsep sehat sakit, hal tersebut secara langsung dapat berakibat fatal pada tingkat kesehatan individu serta masyarakat.

Penelitian lain yang dilakukan Ningsih \& Jonyanis (2014) menyatakan bahwa PHBS yang belum terlaksana sepenuhnya, karena masih banyak terdapat masyarakat yang tentu saja belum peduli terhadap kebersihan lingkungan mereka. Hasil penelitian lain juga menyatakan bahwa tidak semua indikator PHBS dilakukan, salah satunya adalah perilaku merokok sebanyak $60 \%$. Jika dilihat dari penelitian-penelitian yang ada, lebih mengarah pada PHBS yang telah dijalankan maupun yang belum dijalankan serta faktor-faktor yang mempengaruhi pelaksanaaan PHBS, sementara pada penelitian ini lebih menekankan pada persepsi warga mengenai PHBS.

Menariknya dalam penelitian ini, partisipan juga menambahkan beberapa perilaku lain di luar indikator PHBS yang dipersepsikan sebagai bentuk dari perilaku sehat, di antaranya menjaga kebersihan lingkungan tempat tinggal, mengolah limbah atau sampah rumah tangga baik sampah organik maupun anorganik, mandi secara teratur yaitu dua kali sehari, dan menjaga kebersihan organ reproduksi dengan mengganti celana dalam.

Terjadinya gap antara masalah yang terjadi pada lokasi penelitian serta data-data yang tergambar pada penelitian-penelitian terdahulu terhadap upaya pemerintah untuk memperbaiki status kesehatan, peneliti ingin melihat dan mendeskripsikan persepsi warga mengenai PHBS. Peneliti menggunakan 
konsep Health Beliefs Model (HBM) sebagai dasar kerangka berpikir untuk menggambarkan persepsi warga mengenai PHBS. Beberapa poin penting dalam konsep dasar tersebut adalah penilaian terhadap ancaman dan evaluasi perilaku, yaitu persepsi keseriusan (seriousness), keuntungan (benefit), kerentanan (susceptibility), dan rintangan atau hambatan (barrier) (Hayden 2013).

\section{Metode Penelitian}

Metode penelitian yang digunakan dalam penelitian ini adalah kualitatif. Tipe penelitian yang digunakan adalah deskriptif. Peneliti menganalisis persepsi warga mengenai PHBS di Dusun Kebonan, Desa Tolokan, Kecamatan Getasan, Kabupaten Semarang tentang PHBS. Penelitian ini memilih 3 informan secara purposive. Teknik pemilihan informan, yaitu dengan memberikan kriteria warga asli lokal bertempat tinggal di Dusun Kebonan, yang dibuktikan dengan identitas berupa KTP (Kartu Tanda Penduduk), berusia 25 tahun ke atas, dengan pertimbangan dapat berkomunikasi dengan baik, bersedia memberikan informasi sesuai tujuan penelitian, yang ditandai dengan kesediaan mengisi dan menandatangani lembar persetujuan. Penelitian ini dilakukan pada 13 April-5 Mei 2016. Jenis data yang digunakan adalah data primer dan data sekunder. Teknik pengumpulan data primer melalui wawancara mendalam dengan warga Dusun Kebonan, sedangkan data sekunder dengan menggunakan observasi. Uji keabsahan data menggunakan member-checking. Data sekunder didapatkan peneliti dari Data Profil Kesehatan Puskesmas Getasan Tahun 2014, dan Desa Tolokan, Kecamatan Getasan, Kabupaten Semarang tahun 2015. Teknik analisis data yang digunakan dalam penelitian ini adalah model Miles \& Huberman dalam Sugiyono (2010). Tahap pertama analisis data diawali dengan peneliti mengumpulkan semua data yang telah didapatkan dari wawancara mendalam dan membuatnya dalam bentuk verbatim.

\section{Hasil dan Pembahasan}

Peneliti menemukan tiga tema yang menjawab persepsi warga mengenai PHBS. Tiga tema persepsi tersebut tersusun karena melalui proses pembentukan persepsi yang didasarkan pada teori health beliefs model sebagai kerangka berfikir. Warga mempersepsikan PHBS tergambar dalam tiga tema, yaitu mewujudkan kebersihan fisik dan lingkungan, siapa yang bertanggungjawab atas PHBS, serta kendala dalam PHBS.

\section{Pembentukan persepsi mengenai PHBS}

Perilaku kesehatan bergantung pada cara individu mempersepsikan, sehingga memberikan motivasi pada perilakunya yang berasal dari persepsi individu akan kerentanannya terhadap penyakit dan berujung pada pengambilan keputusan individu untuk melakukan tindakan pencegahan atau penyembuhan penyakit (Notoadmodjo 2010). Hal ini sejalan dengan teori Health Beliefs Model (HBM) yang mengelompokkan menjadi empat, yaitu penilaian terhadap ancaman dan evaluasi perilaku, adalah persepsi keseriusan (seriousness), keuntungan (benefit), kerentanan (susceptibility), dan rintangan atau hambatan (barrier) (Hayden 2013).

Berikut ini adalah hasil waawancara dengan partisipan 1, 2 dan 3 (P1,P2,P3) terkait dengan pembentukan persepsi.

\footnotetext{
“....Waduh banyak sekali dampak negatif terutama bagi kesehatan itu ya penyakit itu paru-paru. P1

"Ya...itu kan yang menimbulkan bahaya juga tuh jamban itu, karena itu bisa menimbulkan kuman penyakit itu, seperti sakit perutlah apa itu. P2
}

"kalau sudah sakit nanti yang ada bisa rugi, karena sudah tidak tenang makanpun tidak enak, penyakit juga mudah menyerang, penyakit tambah parah ....Nah misalnya penyakit apa itu, ya sakit gula kan itu.....Nanti juga kalau yang punya banyak penyakit itu kan, makanannya di larang semua. P3 
Dari penuturan di atas tergambar dengan jelas bahwa, P1 mempersepsikan merokok merupakan perilaku yang akan mengganggu kesehatan, karena dapat menyebabkan penyakit paru-paru, sedangkan P2 mempersepsikan jamban yang tidak bersih akan menimbulkan banyak kuman yang dapat menyebabkan sakit perut. Sementara itu P3 mempersepsikan semakin banyak sakit penyakit yang diderita maka akan semakin banyak pantangan makanan, salah satu contoh penyakitnya adalah penyakit gula.

Persepsi terkait ancaman terdiri dari persepsi atau keyakinan individu terhadap keseriusan atau risikorisiko yang ditimbulkan dari suatu penyakit, sehingga memotivasi individu dalam berperilaku, yaitu untuk melakukan pencegahan dan mencari pengobatan penyakit yang disebut juga sebagai persepsi keseriusan. Upaya tersebut dapat didorong oleh tingkat keseriusan penyakit yang dipersepsi maupun risiko yang mungkin ditimbulkan bagi dirinya (Notoatmodjo 2010). Persepsi ini juga seringkali didasarkan pada informasi-informasi medis atau pengetahuan yang juga dapat berasal dari keyakinan individu tentang kesulitan atau dampak yang ditimbulkan oleh penyakit pada kehidupannya secara umum (Hayden 2013).

Persepsi selanjutnya yang terbentuk terkait ancaman adalah persepsi kerentanan. Persepsi kerentanan merupakan penilaian individu terkait kerentanannya terhadap suatu penyakit. Teori HBM juga menyatakan bahwa tindakan pencegahan terhadap suatu penyakit akan timbul bila seseorang merasa dirinya dan keluarganya rentan terhadap penyakit (Hayden 2013). Pada hasil temuan ini, partisipan dalam mempersepsikan kerentanan dirinya dan keluarganya terhadap suatu penyakit juga dikaitkan dengan kerugian-kerugian lain yang menyertai. Seperti rentan terhadap bencana alam (misalnya: banjir dan tanah longsor) dan kerugian materi akibat penyakit. Hal ini mungkin saja dilatarbelakangi oleh pengalaman mereka yang pernah mengalami banjir tahun 2008 silam yang menimbulkan kerugian materi dan masalah-masalah penyakit lainnya. Ditambah dengan pekerjaan ketiganya yang hanya bertani, tentunya akan sangat membebani jika harus mengeluarkan biaya tambahan yang cukup mahal untuk kesehatan. Oleh karena itu, tindakan pencegahan akan dirasakan lebih baik dan menguntungkan untuk dilakukan. Seperti yang dinyatakan oleh ketiga partisipan bahwa penerapan PHBS merupakan salah satu tindakan pencegahan yang dapat membantu mereka terhindar dari ancaman penyakit, kerugian material, dan menjadi sehat serta bahagia.

Akan tetapi, perubahan perilaku dengan mengadaptasi perilaku baru bukan hal yang mudah, karena tergantung pada hambatan-hambatan yang dijumpai dan dipersepsikan oleh masing-masing individu. Jika individu mempersepsikan hambatan itu sebagai penghalang yang cukup besar dan sulit diatasi, maka upaya untuk mengarahkan diri pada pencapaian tujuan akan berkurang sehingga dapat mempengaruhi perubahan perilaku yang sudah direncanakan; khususnya terkait upaya-upaya pencegahan. Evaluasi terhadap rintangan-rintangan inilah yang disebut sebagai persepsi hambatan (Hayden 2013). Hambatan-hambatan tersebut dalam penelitian ini adalah adanya pengaruh negatif lingkungan, kebiasaan, dan keterbatasan biaya serta pengadaan fasilitas. Lingkungan sosial merupakan salah satu faktor interpersonal yang berpengaruh terhadap keputusan berperilaku sehat pada individu.

Dari uraian tersebut, ketiga tema persepsi yang akan dideskripsikan tidak terbentuk dengan sendirinya. Terdapat variabel-variabel yang juga ikut memodifikasi atau mempengaruhi terbentuknya keempat persepsi tersebut. Teori HBM menyatakan bahwa variabel-variabel tersebut antara lain: budaya, tingkat pengetahuan, pengalaman masa lalu, kemampuan individu, dan motivasi. Seluruh variabel ini merupakan karakteristik-karakteristik individual yang mempengaruhi persepsi individu (Notoadmodjo 2010, Hayden 2013).

\section{Mewujudkan kebersihan fisik dan lingkungan}

Persepsi positif yang telah terbentuk dan telah dibahas sebelumnya, rupanya mendorong P1, P2 dan P3 merasa bahwa dalam menciptakan lingkungan yang bersih dibutuhkan peran warga setempat dalam berperilaku sehat. Peran yang dimaksudkan di sini adalah sekelompok tingkah laku atau 
perilaku anggota masyarakat yang berkaitan dengan keberadaan status sosial masyarakat dalam suatu wilayah tertentu terutama dalam hal menjaga kesehatan dan kebersihan lingkungan (Laksana 2013). Hal ini berarti bahwa dalam mewujudkan lingkungan yang bersih dan sehat dibutuhkan peran warga secara keseluruhan, sehingga bukan lingkungan tertentu saja yang bersih dan sehat melainkan semua lingkungan. Mengingat, lingkungan hidup manusia sangat dipengaruhi oleh perilaku warga, yang tentu saja berkaitan dengan peran warga yang berada pada wilayah tersebut (Asmadi 2005).

Artinya, apabila hanya beberapa orang saja yang berperan untuk menjaga kebersihan lingkungan, dari sekian jumlah warga yang tinggal di wilayah tersebut, tanpa didukung oleh peran warga lainnya, maka semua akan terlihat sia-sia saja, dengan kata lain lingkungan yang ada dapat dipastikan tetap menjadi tidak bersih dan sehat. Kondisi demikian akan menciptakan persoalan baru terhadap kesehatan warga setempat bagi mereka yang memiliki wilayah yang tidak bersih dan sehat ditandai dengan munculnya kelompok-kelompok berisiko (Notoatmodjo 2010).

Berikut ini adalah hasil wawancara dengan partisipan 1,2 dan 3 (P1,P2,P3) terkait dengan perilaku utnuk mewujudkan kebersihan fisik dan lingkungan.

“....depan rumah saya kan ada got paling saya bersihin 2 kali sehari apa 3 hari sekali biar nggak mampet. kalo sampah yang anorganik kan langsung saya bakar,apinya digunakan untuk hangatin air. Terus kalo yang organik itu kan, saya taruh di kandang, saya kan punya kandang di sana tempat adek saya, ini kan bisa campuran untuk itu, dan untuk di kebun. Saya selalu BAB di jamban dan sering menguras bak mandi dan bak penampungan air, terus air-air yang menggenang harus dialirkan supaya itu nggak dibuat tempat bertelur seminggu dua kali. Kalo saya cuci tangan ya pake sabun dulu, kalo memang dari kebun, saya kan kadang pegang pupuk atau apa kan cuci tangan pake sabun dulu...".P1

...kalo saya sih sering 2-3 kali sehari ya gimana yah saya bersih-bersih lingkungan rumah bahkan tiap bulan sekali. Kalau sampah dibakar, kalo nggak dibakar dikubur....Misalnya kalo apa itu yang bisa dibakar ya dibakar, kalo yang dibakar ya nggak mempan ya dikubur. Kalo saya langsung mandi, biarpun dua kali ya mandi dua kali gitu. biasanya sih saya mandi dulu baru makan. Ya sementara saya numpang dulu di rumah depan untuk BAB, dulunya ada, numpang dulu sebentar kemarin kan sudah ada bantuan-bantuan itu ya tapi kan belum dapat menjalankan gitu, soalnya belum ada waktu juga. Iya saya cuci tangan, misalnya kalo pulang kerja nggak cuman cuci tangan, misalnya pulang dari kebun bawa apa gitu atau apa gitu. Kalo yang ini sering, apalagi musim hujan begini ya tiap hari. 2-3 kali itu saya bersihkannya.”P2

“....Nggak kalo saya harus cepat pulanglah terus kalo BAB ya di jamban, kalau disana saya nggak bisa keluar. Meskipun harus larinya kayak apa kayak dikejar setan, ya pastinya harus pulang. yang utama kalau yang plastik-plastik itu saya bakar. Tapi kalau misalkan daun-daun itu ya, ya taruh buat nanti pupuk itu. Nggak, saya sering kali cuci tangan, karena tangan kan. Misalnya, saya kan sering naik bis, kan kalau bisnya penuh kan saya selalu pegangan nah itu kan biasanya ada kumannya itu Tiap 3 hari baknya saya bersihkan kalau nggak ya, setiap sudah kotor tetap saya bersihkan pake sabun, terus sikat supaya yang nempel-nempel di bak itu bisa hilang. Kalo saya ya iya mba, biasanya saya beres-beres rumah, ngepel, terus kan itu kita kan cewek ya harus celana dalamnya tuh harus diganti setiap mandi itu kan, biar nggak gatal-gatal organ kewanitaannya itu..."P3

Dari kutipan hasil wawancara dapat kita lihat bahwa frekuensi membersihkan lingkungan fisik, biasanya dilakukan 2-3 kali sehari terutama alam membersihkan lingkungan rumah. Pengelolaan sampah RT dilakukan sesuai dengan jenis sampah, yakni sampah organik maupun anorganik. Pada P1, pengelolaan sampah anorganik (sampah plastik) dengan memanfaatkannya menjadi bahan bakar untuk menghangatkan air, sedangkan untuk sampah organik pada P1 dan P2 memiliki perilaku yang sama, yaitu dengan membuat pupuk dari sampah organik dengan mencampurnya dengan kotoran 
hewan. Sementara itu P3 memilih membakar sampah terkhususnya bagi sampah yang mudah dibakar, dan sampah dikubur jika sampah tersebut tidak bisa dibakar oleh P3. Selain mengelola sampah RT, PHBS lainnya yang dilakukan oleh P1, P2, P3 adalah dengan menggunakan jamban saat BAB (Buang Air Besar) serta mencuci tangan sebelum dan setelah beraktivitas, serta menguras bak mandi. Perilaku menggunakan jamban yang diungkapkan P1, P2, P3, menunjukkan bahwa ketiganya menggunakan jamban untuk BAB. Selain itu perilaku mencuci tangan oleh semua partisipan juga telah dilakukan dengan menggunakan sabun oleh P1 ketika setelah pulang kerja oleh P2 dan P3. P2 menjaga kebersihan dirinya dengan mandi secara teratur, sementara $\mathrm{P} 3$ adalah menjaga kebersihan organ kewanitaan dengan selalu mengganti celana dalam.

Umumnya, banyak hal yang dapat dilakukan warga untuk ikut mewujudkan lingkungan yang bersih dan sehat baik secara pribadi maupun sebagai bagian dari elemen yang mendiami suatu wilayah tertentu yang juga dan ini memiliki keterkaitan dengan perilaku kesehatan. Keterkaitan tersebut, bergantung pada faktor-faktor motivasional dan secara partikular dengan persepsi-persepsi individu terhadap penanganan penyakit, nilai-nilai perilaku dalam mengurangi penanganan (Sarafino 2011), sehingga tidak heran pada kenyataannya masih ditemukan warga yang belum sepenuhnya menciptakan lingkungan yang bersih dan sehat, sementara yang lainnya sudah berperilaku sehat.

Hal ini tentu saja dapat dipengaruhi oleh faktor-faktor lain yang berasal dari dalam maupun dari luar diri individu, bahkan kelompok masyarakat, contohnya masih minimnya kesadaran diri, bahkan sarana dan prasarana penunjang terwujudnya perilaku sehat.

\section{PHBS tanggung jawab siapa?}

Perilaku sehat merupakan segala aktivitas yang ditunjukkan individu untuk mempertahankan atau meningkatkan kesehatannya (Sarafino 2011). Hayden (2013) menambahkan bahwa perilaku sehat juga termasuk segala hal yang dilakukan dan dapat mempengaruhi fisik, mental, emosi, psikologis, dan spiritual.

Berikut ini adalah hasil wawancara dengan partisipan 1,2 dan 3 (P1,P2,P3) terkait dengan subjek yang bertanggungjawab terhadap PHBS.

\footnotetext{
"Kalo menurut saya sih semuanya punya peran penting yaitu seluruh warga itu punya peran penting skali itu, semuanya berperan kalo harus hidup bersih sehat, peran penting banget itu, semuanya...."Karena gini, umpama dari satu keluarga doang itu kan yang bersih hanya satu lingkungan kita sendiri, kalo warga kan bisa keseluruhan sampe satu kampung, satu dusun bisa hidup bersih dan sehat."..."Wah itu sangat penting, karena bila kita contohnya gini....Kalo kita nggak biasa berperilaku hidup sehat, hidup bersih nanti kita ada penyakitnya, nah misalkan itu kan diare tuh, apalagi DB itu kan cacingan juga, nah itu kan nanti kita udah rugi dari segi apa saja umpama kita jatuh sakit diare atau disentri aturan kita ke kebun nggak jadi ke kebun iya kan gitu.". P1
}

\footnotetext{
"Kan kalau nggak semua warga terus kalau sendiri tentu kan nggak bisa. Baiknya jika semua warga menjalankan, kan kalau sebagian warga yang jalankan kan percuma saja kan...."Ya menurut saya itu penting itu." Ya menurut saya itu penting itu."P2

“...Tapi sehat perilaku yang baik itu kan harus karena kita ini kan hidup itu kan meskipun kita banyak harta tapi kalau perilakunya tidak sehat itu juga tidak bagus. Tapi meskipun kita pas-pasan tapi perilakunya kita sehat tapi kan hidupnya kita akan enak aja."...."Ya warga punya peran penting harus itu, karena begini kita ini kan warga, warga kan satu desa. Satu desa kan itu jika dibandingkan satu rumah itu kan sama. Misalkan begini, kalau saya bersih mana tetangga saya nggak bersih nah istilahnya sama aja kan. Lingkungan pasti akan tetap kotor, padahal kita sendiri sudah bersih tapi orang lain tidak misalnya."P3
} 
Pernyataan kutipan wawancara mengenai sikap pro PHBS oleh semua partisipan ditunjukkan dengan sikap ketiganya menganggap bahwa PHBS penting, sehingga memerlukan peran warga secara keseluruhan, untuk dapat menciptakan lingkungan yang bersih dan sehat.

Berdasarkan hasil temuan di lapangan bahwa P1, P2, dan P3 mempersepsikan beberapa perilaku yang dapat dilakukan sebagai perwujudan perilaku sehat diantaranya, penggunaan jamban untuk buang air besar, pemberantasan jentik nyamuk dengan menguras bak mandi, serta mencuci tangan sebelum dan sesudah beraktivitas. Keempat perilaku tersebut sesuai dengan indikator PHBS yang ditetapkan pada tahun 2011 oleh Pusat Promosi Kesehatan Kementerian Kesehatan mencakup 10 indikator, yang sekaligus digunakan dalam PHBS (Riskesdas 2013), yaitu: (1) persalinan oleh tenaga kesehatan, (2) penimbangan bayi dan balita, (3) memberikan ASI eksklusif, (4) mencuci tangan dengan air bersih dan sabun, (5) memakai jamban sehat, (6) melakukan aktivitas fisik setiap hari, (7) konsumsi buah dan sayur setiap hari, (8) tidak merokok di dalam rumah, (9) penggunaan air bersih, dan (10) memberantas jentik nyamuk. Adanya persepsi mengenai perilaku-perilaku sehat yang sesuai dengan indikator PHBS, tentu saja sesuai dengan pengetahuan dan pemahaman yang didapatkan dari masing-masing partisipan tentang PHBS yang sebelumnya telah dibahas.

\section{Kendala dalam PHBS}

Bersamaan dengan persepsi mengenai perilaku sehat, ditemukan juga persepsi mengenai perilaku tidak merokok pada dua orang partisipan laki-laki yang mempersepsikan bahwa perilaku tidak merokok merupakan perilaku yang sulit untuk dihentikan. Berkaitan dengan adanya persepsi mengenai perilaku tidak merokok tersebut, seperti yang telah dijelaskan sebelumnya bahwa beberapa perilaku yang bersifat adiksi umumnya akan sulit sekali untuk diubah bahkan dihilangkan, apalagi perilaku tersebut telah memberikan efek atau dampak yang menyenangkan bagi individu karena terkait dengan emosi. Situasi yang demikian, akan membuat individu cenderung mengabaikan anjuran-anjuran kesehatan dan menolak mempraktikannya dengan berbagai alasan yang bisa saja tanpa mereka sadari sewaktu-waktu dapat menimbulkan masalah kesehatan bagi mereka yang mengabaikan anjuran-anjuran kesehatan tersebut, meskipun mereka sadar akan dampak buruk bagi kesehatan mereka (Sarafino 2011).

Berikut adalah hasil wawancara dengan partisipan 1,2 dan 3 (P1,P2,P3) terkait dengan kendala dalam melakukan PHBS yang dialami oleh warga.

\footnotetext{
"Iya selesai SMP itu, itu saya sudah ngerokok. Pengennya berhenti cuman nggak bisa...." Kalo satu bungkuss itu kan dua belas batang. Kalo saya bangun tidur kan biasanya saya kalo habis sholat subuh saya gosok gigi, bikin minum, terus yang saya ambil dulu bukan apa-apa dulu tapi rokok dulu." P1

"Kalo saya merokok itu, itu saya sudah ngerokok. Pengennya berhenti cuman nggak bisa." P2

"Wah itu nggak tertentu itu, kalo baru nganggur itu ya misalnya rokok yang bungkusan itu ya satu bungkus satu hari."P2
}

Sesuai kutipan pernyataan P1 dan P2 dapat dilihat bahwa keduanya memiliki perilaku tidak sehat yakni merokok sejak kecil, dengan frekuensi merokok satu bungkus per harinya.

Masalah kesehatan yang terjadi tentu saja berkaitan dengan munculnya berbagai macam penyakit yang diakibatkan oleh asap rokok, sehingga berdampak pada aspek kehidupan lainnya (sosial, ekonomi). Oleh karena itu, untuk mengatasi atau menanggulanginya diperlukan lebih dari sekedar informasi dan pengetahuan yang mendalam terkait bahaya penyakit serta akibatnya terhadap kesehatan, sehingga dapat menimbulkan kesadaran yang lebih mendalam dari diri individu. Perlunya pengendalian diri (self-control) oleh masing-masing individu, bahkan masyarakat serta didukung 
oleh partisipasi lingkungan sosial dalam mendorong dan memotivasi mereka untuk meninggalkan persepsi yang tidak sesuai dengan perilaku sehat (PHBS), sehingga kedepannya dapat menciptakan kesejahteraan warga yang optimal dalam berbagai aspek kehidupan diantaranya kesehatan, sosial, maupun ekonomi.

\section{Simpulan}

Hasil temuan penelitian tersebut dapat disimpulkan bahwa persepsi warga Dusun Kebonan mengenai PHBS terbagi menjadi empat bentuk, yaitu: (a) persepsi tentang tingkat keseriusan penyakit (seriousness), (b) persepsi tentang kerentanan terhadap penyakit (susceptibility), (c) persepsi tentang keuntungan (benefits), dan (d) persepsi tentang hambatan atau rintangan yang menghalangi upaya pencegahan yang dilakukan (barries). Keempat persepsi ini saling berkaitan satu dengan yang lain dan dipengaruhi oleh variabel lain (modification variables), seperti pengetahuan dan sosialisasi PHBS, serta keikutsertaan dalam sosialisasi PHBS yang menjadi faktor pendorong tindakan (cues to action). Warga Dusun Kebonan mempersepsikan peran individu dan warga sangat dibutuhkan dalam menciptakan lingkungan yang bersih dan sehat dengan cara menjaga kebersihan lingkungan fisik, mengolah sampah RT, menggunakan jamban, mencuci tangan, mandi serta menjaga kebersihan organ kewanitaan, karena lingkungan yang bersih bergantung pada perilaku. Selain itu, pengendalian diri (self-control), dan dukungan melalui kerja sama dan partisipasi yang baik dari setiap warga juga dibutuhkan untuk terus menjaga dan mempertahankan perilaku sehat dan meninggalkan persepsi yang tidak sesuai dengan perilaku sehat.

\section{Daftar Pustaka}

Asmadi (2005) Konsep Keperawatan Dasar. Jakarta: EGC.

Dinas kesehatan Provinsi Jawa Tengah (2014) Profil kesehatan Jawa Tengah 2014. [Diakses 26 Januari 2016]. www.depkes.go.id.

Gomo M J, Umboh JML, Pandelaki J (2013) Gambaran perilaku hidup bersih dan sehat (PHBS) sekolah pada siswa kelas akselerasi di SMPN 8 Manado 2. Bagian ilmu kedokteran masyarakat Fakultas Kedokteran Universitas Sam Ratulangi Manado. Jurnal e-Biomedik (EBM) 1 (1) Maret 2013:503-505.

Hayden JA (2013) Introduction to Health Behaviour Theory: Second Edition. Jones and Barlett Publisher.

Laksana SN (2013) Bentuk-bentuk Partisipasi Masyarakat Yogyakarta. Surabaya: Universitas Airlangga.

Notoatmodjo S (2010) Ilmu Perilaku Kesehatan. Jakarta: Rineka Cipta.

Pemerintah Kabupaten Semarang, Kecamatan Getasan, Desa/Kelurahan Tolokan Kecamatan Getasan tahun 2016. Kabupaten Semarang.

Profil kesehatan Puskesmas Getasan tahun 2014. Resume Kesehatan Kabupaten Semarang 2014. Kabupaten Semarang: Puskesmas Getasan.

Sarafino EP (2011) Health Psychology: Biopsychosocial Interactions Seven Edition. United States of America (USA): Wiley.

Sugiyono (2010) Memahami Penelitian Kualitatif. Bandung: Alfabeta. 